\title{
The characteristics and origins of carbonaceous aerosol at a rural site of PRD in summer of 2006
}

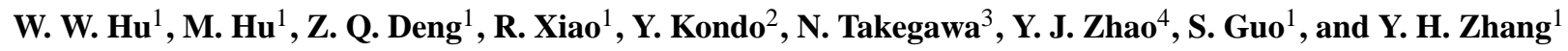 \\ ${ }^{1}$ State Key Joint Laboratory of Environmental Simulation and Pollution Control, College of Environmental Sciences and \\ Engineering, Peking University, Beijing 100871, China \\ ${ }^{2}$ Department of Earth and Planetary Science, Graduate School of Science, University of Tokyo, Tokyo, Japan \\ ${ }^{3}$ Research Center for Advanced Science and Technology, University of Tokyo, Tokyo, Japan \\ ${ }^{4}$ Air Quality Research Center, University of California, Davis, CA 95616, USA \\ Correspondence to: M. Hu (minhu@pku.edu.cn)
}

Received: 6 July 2011 - Published in Atmos. Chem. Phys. Discuss.: 29 July 2011

Revised: 6 January 2012 - Accepted: 7 January 2012 - Published: 17 February 2012

\begin{abstract}
Both organic carbon (OC) and elemental carbon (EC) were measured during PRIDE-PRD 2006 summer campaign by using a semi-continuous thermal-optical carbon analyzer at a rural site, Back Garden (BG), which is located $50 \mathrm{~km}$ to the northwest of Guangzhou City. Together with the online EC/OC analyzer, various kinds of instruments related to aerosol chemical properties were employed here, which provided a good opportunity to check data quality. The concentrations of OC correlated well with the mass of organic matter (OM) and water soluble organic carbon (WSOC), implying the reliability of the data measured in this campaign. The average OC concentrations in fine particle for three typical periods during the campaign (local emission influence, typhoon and precipitation and normal days) were $28.1 \mu \mathrm{gC} \mathrm{m}{ }^{-3}, 4.0 \mu \mathrm{gC} \mathrm{m}^{-3}$ and $5.7 \mu \mathrm{gC} \mathrm{m}^{-3}$, respectively; and $\mathrm{EC}$ were $11.6 \mu \mathrm{gC} \mathrm{m}^{-3}, 1.8 \mu \mathrm{gC} \mathrm{m}{ }^{-3}$, and $3.3 \mu \mathrm{gC} \mathrm{m}{ }^{-3}$, respectively. The diurnal patterns of $\mathrm{EC}$ and $\mathrm{OC}$ during the campaign were higher at night and in early morning than daytime, which was probably caused by the primary emission and accumulation in the occurrence of low boundary layer. Compared with the constant diurnal enhancement ratios of EC, the enhancement ratio of OC (OC versus (CO$\left(\mathrm{O}_{\text {background }}\right)$ ) kept in a relative high level in the afternoon, with a similar diurnal profile to oxygenated organic aerosol (OOA), due to the strong photochemical formation of OC. Here, a modified EC tracer method was used to estimate the formation of secondary organic carbon (SOC). These results showed that the average SOC concentration (normal days) at BG site was about $2.0 \pm 2.3 \mu \mathrm{gC} \mathrm{m}{ }^{-3}$, and the $\mathrm{SOC}$ fraction in OC could reach up to $80 \%$ with the average of $47 \%$. The modified approach in this study proved to be effective and
\end{abstract}

reliable for SOC estimation based on good correlations between estimated SOC versus OOA or WSOC, and estimated POC versus hydrocarbon-like organic aerosol (HOA).

\section{Introduction}

Carbonaceous aerosol is the main constituent $(20-80 \%$ of fine particle) in the particulate matter (Lim and Turpin, 2002). Recently, carbonaceous aerosol has become one of the most hot research topics due to its important role in climate and health effects, as well as its extreme complex properties (Ho et al., 2006). However, the classification methods of carbonaceous aerosol varies with different detection methods (Lin et al., 2009). It is commonly used to divide carbonaceous aerosol into two main fractions, i.e. organic carbon (OC) and element carbon (EC), according to thermal or optical analysis methods. EC is emitted directly by primary combustion sources such as biomass burning (Andreae and Gelencser, 2006), vehicular exhaust (He et al., 2008) and coal combustion (Han et al., 2008). OC is a poorly characterized aggregation of thousands of individual compounds from different sources (Seinfeld and Pandis, 1998). In general, OC can be ascribed to primary organic carbon (POC) emitted by combustion and primary biogenic sources, and secondary organic carbon (SOC) formed by the oxidations of volatile organic compounds (VOCs) (Odum et al., 1997).

The state-of-art speciation techniques can identify only a small part of organic species in aerosol on the molecular level. The influences of emission sources and atmospheric oxidation processes on carbonaceous aerosol are on the time 


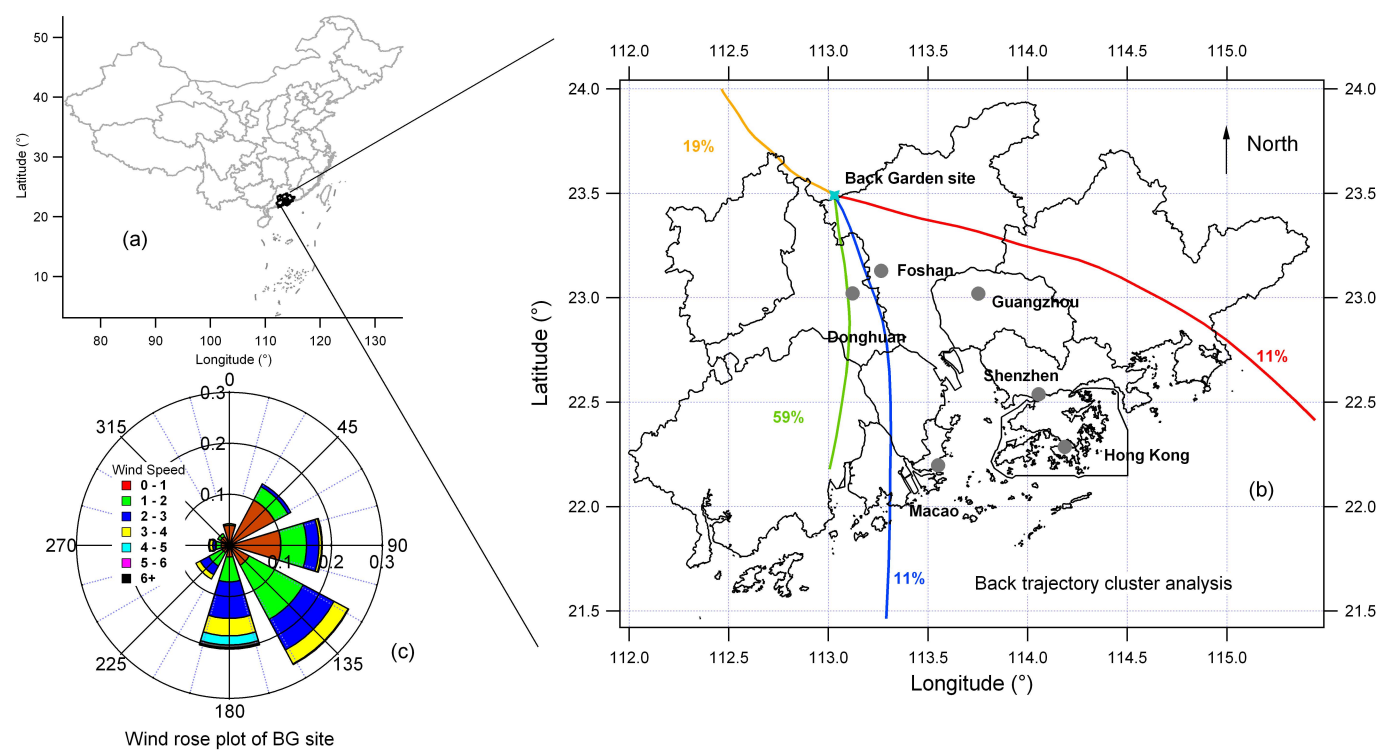

Fig. 1. (a) Map of the PRD area in China. (b) Location of Back Garden site (BG) and major cities related in this study, and also showed the back trajectory cluster analysis results. (c) Wind rose plot of BG site in July 2006.

scale of minutes to hours (Schauer et al., 1996). Therefore, high-time resolved estimation of POC and SOC contributions becomes an important and useful way to understand secondary organic formation processes (Lim and Turpin, 2002). At present, one of the widely used methods for SOC estimation is the EC tracer method, owing to its simplicity and reliance on ambient measurements alone (Turpin and Huntzicker, 1995; Cabada et al., 2004).

Pearl River Delta (PRD) region is the most developed city cluster, is located in southeast China and is heavily influenced by urban emissions (Cao et al., 2003). A few studies on carbonaceous aerosol in the PRD region were conducted and relative high concentrations were usually detected, which were comparable to those in Beijing and Mexico City (Lin et al., 2009; Yu et al., 2009; Gnauk et al., 2008). However, most of the previous studies were based on filter-sampling with low time resolution ( $12 \mathrm{~h}$ or $24 \mathrm{~h}$ ) (Cao et al., 2004; Duan et al., 2007; Ho et al., 2003; Yu et al., 2010), which cannot reflect dynamic evolution processes of carbonaceous aerosol within one day. Therefore, a higher time resolution research of carbonaceous aerosol in PRD region is needed to explore primary emissions and secondary formation.

The Program of Regional Integrated Experiments of Air Quality over Pearl River Delta 2006 (PRIDE-PRD 2006) was conducted in July 2006, in which both EC and OC were measured by online Sunset EC/OC instrument from 3 July to 31 July. It was the first time that hourly averaged time resolution concentrations of OC and EC at a rural site of PRD were measured. The study focus was twofold: (1) to find the time variation characteristics of carbonaceous aerosol at a rural site of PRD; and (2) to distinguish and quantify the contri- butions of primary and secondary sources to carbonaceous aerosol.

\section{Experimental}

\subsection{Meteorology}

The measurement was conducted at the rural Back Garden $(\mathrm{BG})$ site $\left(23.49^{\circ} \mathrm{N}, 113.03^{\circ} \mathrm{E}\right)$ located about $50 \mathrm{~km}$ northwest to the Guangzhou City (Fig. 1). The BG site was situated on the edge of the highly populated PRD region, though the site was surrounded by farming land (Garland et al., 2008). The meteorology parameters were measured by Weather Transmitter (WXT510, Vaisala, Finland). The average temperature of $\mathrm{BG}$ site was about $28.9 \pm 3.2^{\circ} \mathrm{C}$ during the campaign, which was lower than Guangzhou City by $1.6^{\circ} \mathrm{C}$; the relative humidity (RH) there was $78.0 \pm 13.7 \%$ and ambient pressure was $997 \pm 4 \mathrm{hpa}$. The back trajectory clustering results obtained by HYSPLIT 4.9 model (http://ready.arl.noaa.gov/hysplit-bin/trajtype.pl? runtype $=$ archive) showed that the wind direction of BG site was mainly from southeast or south ( $81 \%$ of the campaign). Thus, the BG site acted as a rural receptor to receive outflows from the heavily polluted city cluster around Guangzhou (Yue et al., 2010).

\subsection{Measurement instruments}

During the PRIDE-PRD 2006 campaign, a number of instruments were used to measure aerosol and gas pollutants, and those field experiments supported us in fulfilling a comprehensive study on carbonaceous aerosols. The observation 


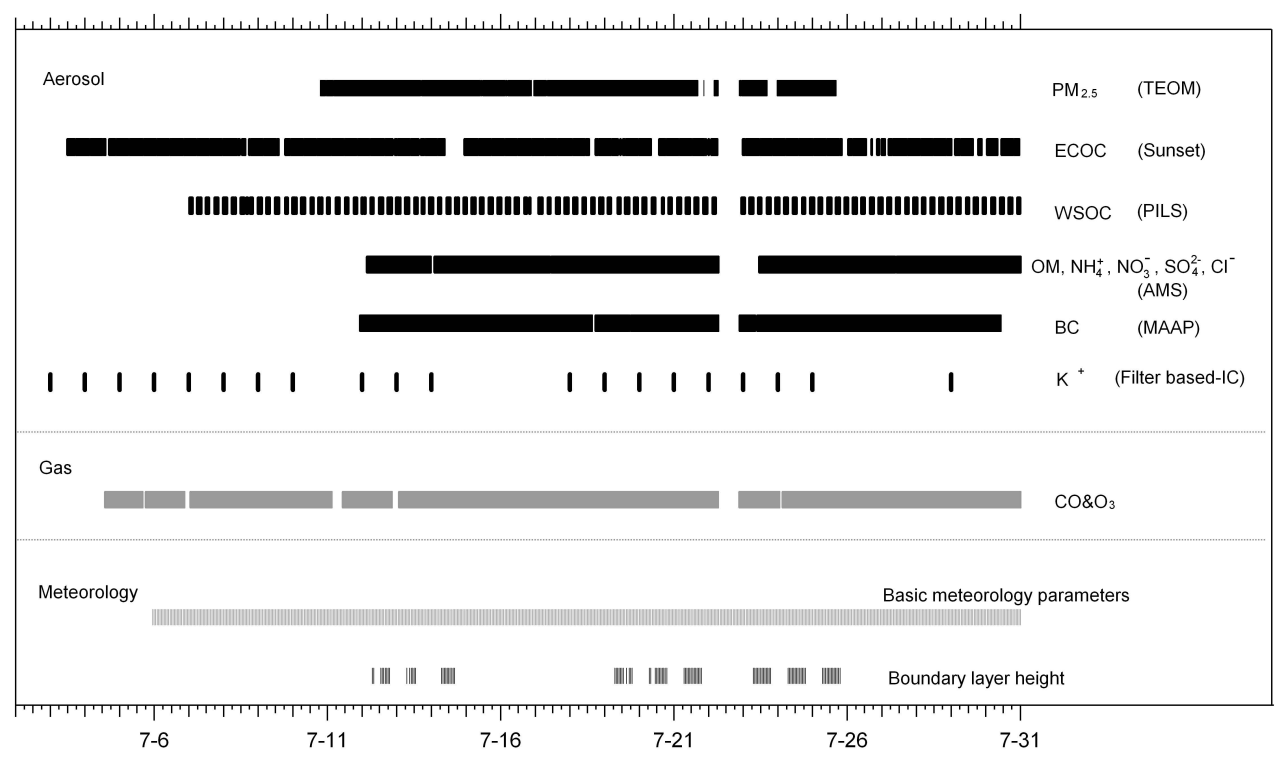

Fig. 2. The instruments used to measure aerosol and gas species at BG site in PRIDE-PRD 2006 campaign.

periods of different instruments are shown in Fig. 2 and brief descriptions of these instruments are given below.

The OC and EC concentrations in fine particle were measured hourly by an in situ semi-continuous OC/EC analyzer manufactured by Sunset Laboratory Inc. (Lin et al., 2009). The ambient aerosol was collected on a $1.03 \mathrm{~cm}^{2}$ quartz filter through an $81 \mathrm{~min}^{-1}$ cyclone at a cut size of $\mathrm{PM}_{2.5}$ (from 3 to 16 July) and $\mathrm{PM}_{1}$ (from 17 to 31 July), then was analyzed by using improved NOISH 5040 temperature protocol. A denuder filled with carbon impregnated strip filters was set up to remove the artifacts of VOCs in front of the EC/OC instrument. The OC concentrations in this campaign were corrected by subtracting the remaining VOCs artifacts from the measured OC concentrations (around $2.0 \mu \mathrm{gC} \mathrm{m}^{-3}$ ). More detailed description of the Sunset OC and EC analyzer can be found in Lin et al. (2009). Particle size distribution obtained by twin differential mobility particle size (TDMPS) showed the difference between $\mathrm{PM}_{2.5}$ and $\mathrm{PM}_{1}$ was negligible in this research (Yue et al., 2010). Volume size distribution data of EC indicated that EC in $\mathrm{PM}_{1-2.5}$ only had $10 \%$ of that in $\mathrm{PM}_{2.5}$ at BG site (Yu et al., 2010). The OM/OC ratio in $\mathrm{PM}_{2.5}$ detected in the first half period of the campaign was similar to that in $\mathrm{PM}_{1}$ in the second half period (Miyazaki et al., 2009). Therefore, the OC and EC data will be discussed without differentiating between $\mathrm{PM}_{2.5}$ and $\mathrm{PM}_{1}$ in the following discussion.

The $\mathrm{OM}$ and inorganic ions (sulfate, nitrate, ammonium and chloride) were measured by a quadrupole aerosol mass spectrometry instrument (Q-AMS, Aerodyne Research Inc.). More specific descriptions of the instrument performance are given in previous studies (Takegawa et al., 2009; Xiao et al., 2011). The time resolution of AMS was $10 \mathrm{~min}$ and collection efficiency was adopted as 0.5 . The accuracy of measurements was estimated to be $14 \%$ based on the routine calibrations. The detection limits were $0.09,0.03,0.03$, 0.5 and $0.4 \mu \mathrm{g} \mathrm{m}^{-3}$ for $\mathrm{SO}_{4}^{2-}, \mathrm{NO}_{3}^{-}, \mathrm{Cl}^{-}, \mathrm{NH}_{4}^{+}$and $\mathrm{OM}$, respectively. The $\mathrm{OM}$ was divided into hydrocarbon-like organic aerosol (HOA) and oxygenated organic aerosol (OOA) $(\mathrm{OOA}=$ low volatility $(\mathrm{LV})-\mathrm{OOA}+$ Semi-volatile (SV)-OOA) by applying positive matrix factorization (PMF) method to mass spectra (Xiao et al., 2011).

Water soluble organic compound (WSOC) in aerosols was collected by a particle-into-liquid sampler (PILS). The details of the performance of PILS are given elsewhere (Miyazaki et al., 2009). The ambient aerosol was sampled at a flow rate of $16.71 \mathrm{~min}^{-1}$ through a $\mathrm{PM}_{2.5}$ cyclone. After particles were sampled, WSOC was quantified by an online total organic carbon (TOC) analyzer with a time resolution of $6 \mathrm{~min}$ and detection limit of $0.1 \mu \mathrm{g} \mathrm{m}^{-3}$.

The mass concentration of fine particle $\left(\mathrm{PM}_{2.5}\right)$ was measured by Tapered Element Oscillating Microbalance (TEOM) every half an hour. In addition, 24-h $\mathrm{PM}_{2.5}$ samples were collected on the Teflon filers by using a four channels sampler (Anderson Inc.) at a flow rate of $8.31 \mathrm{~min}^{-1}$. Water soluble ions including potassium ion $\left(\mathrm{K}^{+}\right)$were analyzed by ion chromatography (ICS-90). The detection limit of $\mathrm{K}^{+} \mathrm{W}$ as $0.1 \mu \mathrm{g} \mathrm{m}^{-3}$.

CO concentrations were measured by Enhanced Trace Level CO Analyzer with an integration time of 1 min (48CTLE-BCPAB, Thermo fisher company, USA). A Nafion dryer was used before the inlet of the instrument to purify sample air and avoid the interference of water vapor. Zero calibrations were done every two hours and span calibrations were done daily. Meanwhile, ozone $\left(\mathrm{O}_{3}\right)$ concentrations were measured by an UV absorption ozone analyzer (49CB1NAB, Thermo Fisher Company) at a time resolution of 


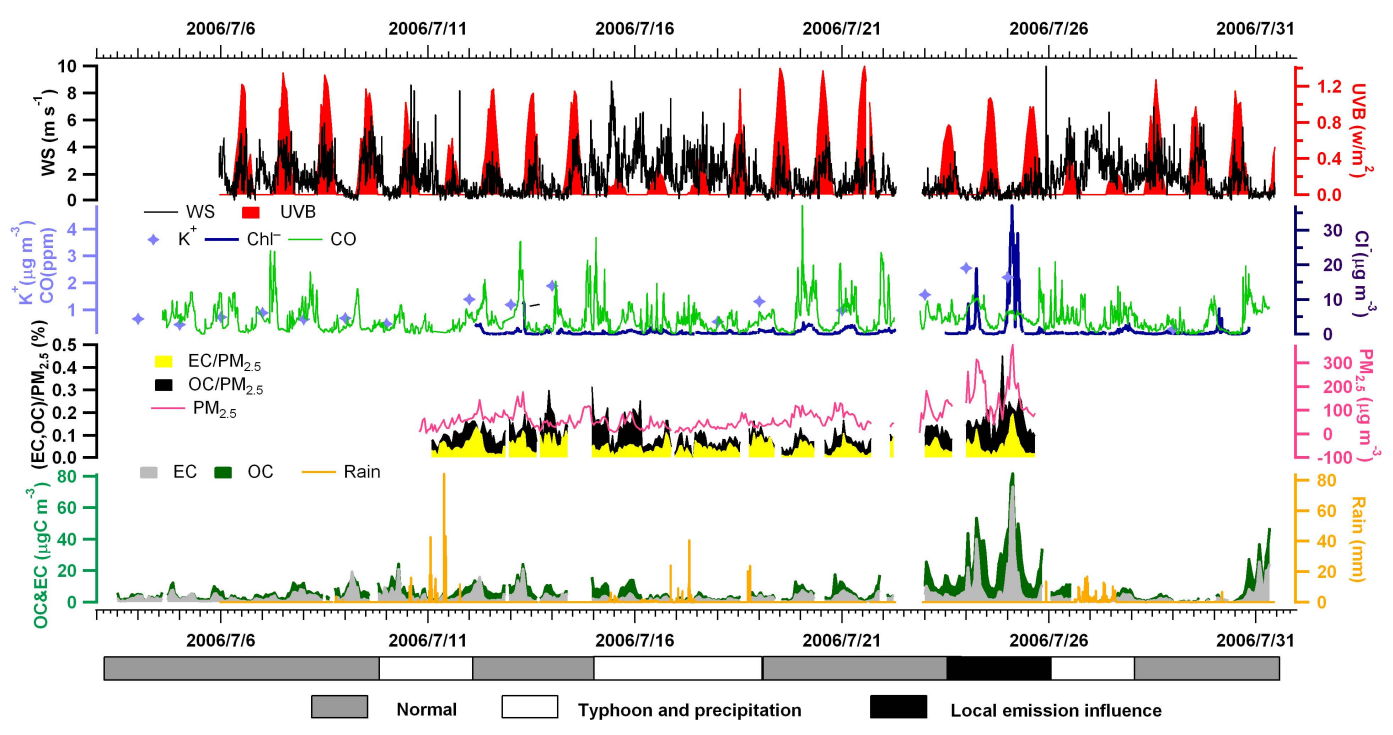

Fig. 3. The time series mass concentrations of $\mathrm{PM}_{2.5}, \mathrm{EC}, \mathrm{OC}, \mathrm{Cl}^{-}, \mathrm{K}^{+}$and meteorology conditions during PRIDE-PRD 2006 campaign. The whole campaign was divided into three typical periods: normal days (grey bar), typhoon and precipitation days (white bar), and local emission influence days (black bar).

1 min. Boundary layer height was detected by Mini-MAXDOAS (Li et al., 2010).

\section{Results and discussions}

\subsection{The time series of carbonaceous aerosol}

The time series of mass concentrations for carbonaceous aerosol and the meteorological parameters are shown in Fig. 3. During the PRIDE-PRD 2006 campaign, the mass concentrations of carbonaceous aerosol in $\mathrm{PM}_{2.5}$ varied dramatically. According to local emission influences and meteorology condition at BG site, we define three types of periods: normal days (grey bars, Fig. 3), typhoon and precipitation days (white bars), and local emission influence days (black bar).

Local emission influence days ( $8 \%$ of total days) were characterized by high concentrations of carbonaceous aerosol starting from noon, 23 July to midnight, 25 July. The average $\mathrm{OC}$ and $\mathrm{EC}$ concentrations in this period were $28.1 \pm 17.6 \mu \mathrm{gC} \mathrm{m}{ }^{-3}$ and $11.6 \pm 15.1 \mu \mathrm{gC} \mathrm{m}{ }^{-3}$, respectively (Table 1). Two increasing peaks of carbonaceous aerosol with OC (up to $82 \mu \mathrm{gC} \mathrm{m}{ }^{-3}$ ) and EC (up to $76 \mu \mathrm{gC} \mathrm{m}{ }^{-3}$ ) were recorded (Fig. 3). The carbonaceous aerosol accounted for nearly $50 \%$ of the total $\mathrm{PM}_{2.5}$ in this period. Meanwhile, the OC/EC ratio dropped sharply to about 1 , indicating that the increased OC concentrations were mainly attributed to local primary combustion sources. $\mathrm{Cl}^{-}$concentrations in local emission influence days increased rapidly from $0.9 \mu \mathrm{g} \mathrm{m}^{-3}$ (the average concentration during the whole campaign) to $18.8 \mu \mathrm{g} \mathrm{m}^{-3}$ (06:00, 24 July) and $37.7 \mu \mathrm{g} \mathrm{m}^{-3}$
(02:40, 25 July) respectively, which also suggested aerosol was strongly influenced by local emission sources. In addition, stagnant meteorological condition with relatively low wind speeds $\left(<1 \mathrm{~m} \mathrm{~s}^{-1}\right)$ also facilitated the accumulation of pollutants. Garland et al. (2008) reported the local emissions were from the burnings of plant wastes by local farmers. However, in view of the high OC/EC ratio from biomass burning (Akagi et al., 2011), low OC/EC ratios in local emission days may not support this point.

Typhoon and precipitation days (27\% of total days) were characterized by lower concentrations of carbonaceous aerosol. During the PRIDE-PRD 2006 campaign, there were three precipitation events of 10-11, 15-18, 26-27, July, and the last two precipitations were caused by the two typhoons, Bilis and Kaemi, respectively (http://en.wikipedia.org/wiki/ 2006_Pacific_typhoon_season). Heavy rainfalls and strong winds broke up the accumulation processes of pollutants, and the average levels of OC and EC concentrations decreased in these days, which were $4.0 \pm 2.8 \mu \mathrm{gC} \mathrm{m}^{-3}$ and $1.8 \pm 1.2 \mu \mathrm{gC} \mathrm{m}^{-3}$, respectively (Table 1 ).

Normal days (65\% of total days): The remaining observational days are defined as normal days, which reflected the usual atmospheric condition. The average OC and EC concentrations in these periods were $5.7 \pm 4.5 \mu \mathrm{gC} \mathrm{m}{ }^{-3}$ and $3.3 \pm 2.8 \mathrm{\mu gC} \mathrm{m}^{-3}$, respectively (Table 1).

The concentrations of $\mathrm{OC}$ and $\mathrm{EC}$ in various cities are summarized in Table 2. Because of the influence of Guangzhou city clusters (Yue et al., 2010), it is rational to find that the concentrations of $\mathrm{OC}$ and $\mathrm{EC}$ at BG site were a little lower than those of Guangzhou during the same period (Verma et al., 2010). OC and EC concentration levels at both 
Table 1. Comparisons of carbonaceous aerosol concentrations in three typical periods in the PRIDE-PRD 2006 campaign.

\begin{tabular}{lllll}
\hline Classification of measurement period (time periods) & $\mathrm{OC}\left(\mu \mathrm{gC} \mathrm{m}{ }^{-3}\right)$ & $\mathrm{EC}\left(\mu \mathrm{gC} \mathrm{m}{ }^{-3}\right)$ & $\mathrm{TC}^{*} / \mathrm{PM}_{2.5}(\%)$ \\
\hline Typhoon and precipitation days & $10-11,15-18,26-27$ July 2006 & $4.0 \pm 2.8$ & $1.8 \pm 1.2$ & 12.5 \\
Local emission influence days & $23-25, \mathrm{July}, 2006$ & $28.1 \pm 17.6$ & $11.6 \pm 15.1$ & 18.2 \\
Normal days & except the two periods above & $5.7 \pm 4.5$ & $3.3 \pm 2.8$ & 10.1 \\
\hline Total in average & $7.6 \pm 5.7$ & $3.7 \pm 5.7$ & 13.6 \\
\hline
\end{tabular}

$* \mathrm{TC}=\mathrm{OC}+\mathrm{EC}$

Table 2. Comparisons of carbonaceous aerosol concentration with other studies in China and other countries.

\begin{tabular}{|c|c|c|c|c|c|c|c|}
\hline Location & $\begin{array}{l}\text { Station types } \\
\text { and mayor source }\end{array}$ & Period & $\begin{array}{l}\text { Analysis } \\
\text { Method }\end{array}$ & $\begin{array}{l}\mathrm{OC} \\
\left(\mu \mathrm{gCm}^{-3}\right)\end{array}$ & $\begin{array}{l}\mathrm{EC} \\
\left(\mu \mathrm{gCm} \mathrm{m}^{-3}\right)\end{array}$ & $\begin{array}{l}\text { SOC/OC } \\
\text { or WSOC/OC }(\%)\end{array}$ & Reference \\
\hline BG, China & $\begin{array}{l}\text { Regional site; } \\
\text { Downwind of the } \\
\text { Urban (Normal days) }\end{array}$ & $\begin{array}{l}\text { July } 2006 \\
\text { (normal day) }\end{array}$ & TOT & 5.7 & 3.3 & 47 & This study \\
\hline BG, China & $\begin{array}{l}\text { Regional site; Down- } \\
\text { wind of the Urban }\end{array}$ & July 2006 & TOT & $2.9^{\mathrm{d}}$ & $1.36^{\mathrm{d}}$ & Not available & Yu et al. (2010) \\
\hline Cong Hua, China & Regional site & $\begin{array}{l}\text { Oct, Dec 2002; } \\
\text { Mar, Jun } 2003\end{array}$ & TOT & 8.1 & 1.4 & Not available & Hagler et al. (2006) \\
\hline Guangzhou, China & $\begin{array}{l}\text { Urban site; Vehicle, } \\
\text { industrial, domestic } \\
\text { activities }\end{array}$ & July 2006 & TOT & $8.9^{\mathrm{e}}$ & 4.7 & Not available & Verma et al. (2009) \\
\hline Guangzhou, China & Urban site & April 2007 & TOR & 14.8 & 8.1 & 29 & Tao et al. (2009) \\
\hline Beijing, China & Urban site & Summer 2006 & TOT & 10.0 & 2.2 & 45 (day); 17 (night) & Lin et al. (2009) \\
\hline Hong Kong, China & Regional site & Summer 2006 & TOR & 1.5 & 0.4 & $69^{g}$ & Ho et al. (2006) \\
\hline Gwangiu, Korea & $\begin{array}{l}\text { Urban site; motor } \\
\text { vehicle emission }\end{array}$ & March-May 2001 & TOT & 15.7 & 5.7 & 62 & Park et al. (2005) \\
\hline T0, Mexico ${ }^{\mathrm{a}}$ & Urban site & March 2006 & TOR & $10.7^{\mathrm{f}}$ & 4.2 & $46^{\mathrm{h}}$ & $\begin{array}{l}\text { Aiken et al. } \\
\text { (2008 2008, 2009) }\end{array}$ \\
\hline $\mathrm{T} 1$, Mexico $^{\mathrm{b}}$ & $\begin{array}{l}\text { Suburb site; Downwind } \\
\text { of the urban }\end{array}$ & March, 2006 & TOT & 6.4 & 2.1 & 63.6 & Yu et al. (2009) \\
\hline $\mathrm{T} 2$, Mexico $^{\mathrm{c}}$ & $\begin{array}{l}\text { Non-urban site; Down- } \\
\text { wind of the urban }\end{array}$ & March 2006 & TOT & 5.4 & 0.6 & 67.4 & Yu et al. (2009) \\
\hline Pittsburgh, USA & $\begin{array}{l}\text { Regional site; No local } \\
\text { emmissions }\end{array}$ & $\begin{array}{l}\text { July 2001-August } \\
2002\end{array}$ & TOT & 2.75 & 0.89 & 38 & Polidori et al. (2006) \\
\hline Barcelona, Spain & $\begin{array}{l}\text { Urban background site; } \\
\text { influenced by traffic } \\
\text { emission transportation }\end{array}$ & Summer 2004 & TOT & 3.6 & 1.5 & $43 / 47^{\mathrm{g}}$ & Viana et al. (2007) \\
\hline
\end{tabular}

a T0 site was an urban site located in the center of Mexico City.

$\mathrm{b} \mathrm{T} 1$ site was a suburb site in the down wind direction of Mexico City.

c $\mathrm{T} 2$ site was a regional background site of Mexico City.

$\mathrm{d}$ The concentrations of OC and EC were the sum of the values in condensation mode $(0.36-0.46 \mu \mathrm{m})$ and droplet mode $(0.8-1.1 \mu \mathrm{m})$.

e Personal communication.

$\mathrm{f}$ The concentration of OC is calculated by OM/1.71.

g Refer to the WSOC/OC.

$\mathrm{h}$ The data was calculated from OOA/OA.

TOT: thermal/optical transmission. TOR: thermal/optical reflectance.

the Guangzhou urban site (Verma et al., 2010) and BG rural site in the PRD region were comparable with those in Mexico City, one of the most heavily polluted mega-cities in the world (Aiken et al., 2009; Yu et al., 2009). The other downwind rural sites (Ho et al., 2006; Polidori et al., 2006; Viana et al., 2007) are also listed in the Table 2. During the summer time, the carbonaceous aerosol concentrations (especially for EC) in PRD were substantially higher than other rural sites, as shown in Table 2.

\subsection{The correlation of $\mathrm{OM}$ and WSOC versus OC}

The OM and OC concentrations showed good correlations both in primary emission days and the other days (normal days, typhoon and precipitation days) (both $R^{2}$ were 0.83 ) in Fig. 4a. During the primary emission days, the OM/OC ratio was about 1.7 , which was a little lower than in the normal and typhoon and precipitation days (1.98). Previous studies showed that the more aged air masses tend to have higher 

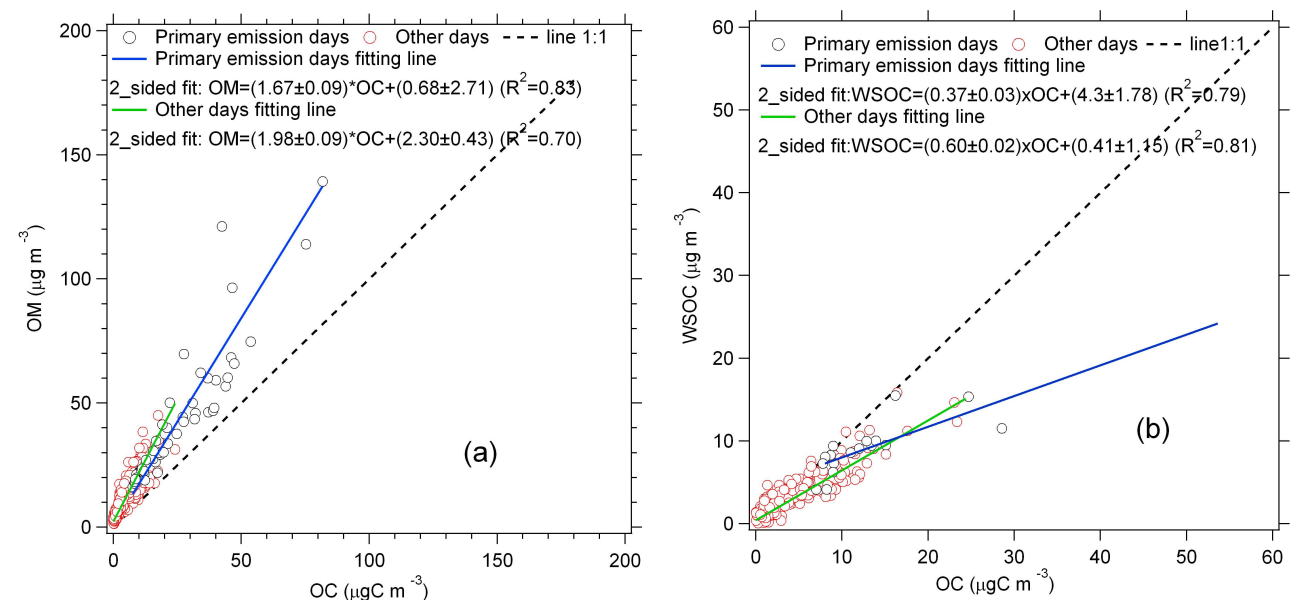

Fig. 4. The correlations of measured data between (a) OM and OC; (b) WSOC and OC.

OM/OC ratio, about $1.4-1.6$ in urban area and about 2.0-2.5 for oxygenated aerosol (Aiken et al., 2008; Turpin and Lim, 2001), which implied the OM and OC in the other days were more aged than that in primary emission days.

WSOC and OC concentrations in primary emission days and the other days also showed good correlations $\left(R^{2}\right.$ were 0.79 and 0.81 , respectively) in Fig. 4b. The WSOC/OC ratios at BG site during the whole period were within the expected range $(20 \%$ to $80 \%)$ reported by previous studies (Kondo et al., 2007). The averaged WSOC/OC ratio in the other days $(60 \%)$ was much higher than that in primary emissions days $(37 \%)$. It is reported that WSOC/OC ratio was larger in summer $(0.4-0.8)$ than that in winter $(0.2-0.4)$ in Tokyo (Kondo et al., 2007). Higher WSOC/OC ratio can be regarded as indicative of a more sufficient photochemical reaction, so the secondary formation in other days was stronger.

The good correlations among different carbonaceous aerosol components suggest that the OC measured by the Sunset carbon analyzer are reliable for the SOC data processing in the following part.

\subsection{Diurnal profile of carbonaceous aerosol}

Pronounced diurnal variations were observed for primary species EC and CO, as shown in Fig. 5a and c. To reflect the usual characteristics of carbonaceous aerosol at BG site, only normal days data were used in this section. The averaged EC concentration varied in large amplitude with the value of peak at night, being 4 times higher than that of valley in the afternoon. EC concentrations kept in high levels during the nighttime and early morning, probably due to the accumulation of direct emissions at night and the shallow boundary layer. After sunrise, EC dropped sharply due to the quickly rising boundary layer heights (Fig. 5d) and increasing wind speeds, and it decreased to the lowest $\left(1.2 \mu \mathrm{gC} \mathrm{m}{ }^{-3}\right)$ at 14:00 in the afternoon. After 16:00, EC concentrations increased again because of the descending boundary layer height. $\mathrm{CO}$ showed very similar variations with EC, indicating the same emission sources of the two pollutants. The averaged OC was also found to display similar diurnal pattern with two peaks at 6:00 $\left(6.8 \mu \mathrm{gC} \mathrm{m}{ }^{-3}\right)$ and 19:00 $\left(8.0 \mu \mathrm{gC} \mathrm{m}{ }^{-3}\right)$, but the concentrations of $\mathrm{OC}$ were about two times higher than those of EC (Fig. 5b). However, there was no obvious decrease of OC in the daytime, which might be explained by the secondary organic formation.

In order to evaluate secondary formation of organic aerosol, $\mathrm{CO}$ was used as a combustion tracer to normalize OC and EC concentrations for excluding the influence of primary emissions and transport (de Gouw et al., 2009). The diurnal profiles of different aerosol species versus (CO$\mathrm{CO}_{\text {Background }}$ ) were demonstrated in Fig. 6. The background concentration of $\mathrm{CO}$ was calculated as the lowest 5 percentile of $\mathrm{CO}$ concentrations $(0.16 \mathrm{ppm})$ observed during the normal days of campaign (Miyazaki et al., 2009).

As shown in Fig. 6a, the ratios of EC/(CO-0.16) were scaled from 2.5 to $12.5 \mu \mathrm{g} \mathrm{m}^{-3} \mathrm{ppm}^{-1}$, with an average of $7.9 \mu \mathrm{g} \mathrm{m}^{-3} \mathrm{ppm}^{-1}$. The diurnal variation of enhancement ratio of EC was relative flat, indicating the similar emission sources of EC and CO. The diurnal EC profile shown here is also similar to the results at suburb T1 site in Mexico City (de Gouw et al., 2009).

OOA obtained by AMS is regarded as typical secondary product. The diurnal variation of OOA (Fig. 6d) showed an extremely high enhancement ratio in the afternoon, implying strong secondary organic formation in this period. OC and $\mathrm{OM}$ enhancement ratios (Fig. $6 \mathrm{~b}$ and c) displayed similar variations to OOA, suggesting secondary formations also played important roles in both OC and OM concentrations. Interestingly, the lowest enhancement ratio of $\mathrm{OC}$ to $\mathrm{CO}$ in the morning (08:00) and the highest ratio in the noon (12:00) agreed well with those corresponding ratios determined in the northeast US (de Gouw et al., 2009). Overall, the contributions of secondary formation to OC or OM were clearly 

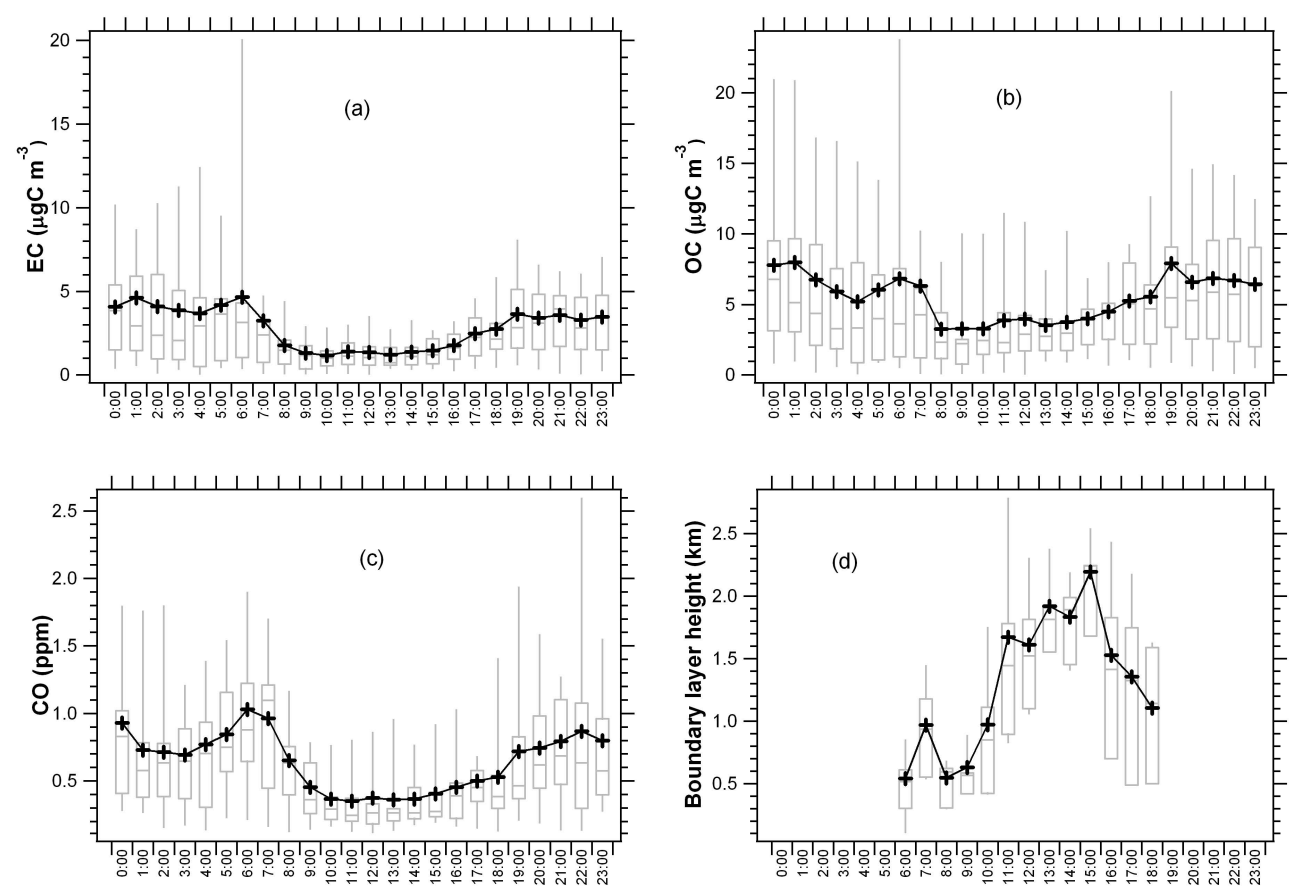

Fig. 5. Diurnal variation box plots of EC (a), OC (b), CO (c), and boundary layer height (d). The upper and lower boundaries of boxes indicate the 75th and 25th percentiles; the lines within the box mark the median; the whiskers above and below boxes indicate the 90th and 10th percentiles; and cross symbols represent the means.
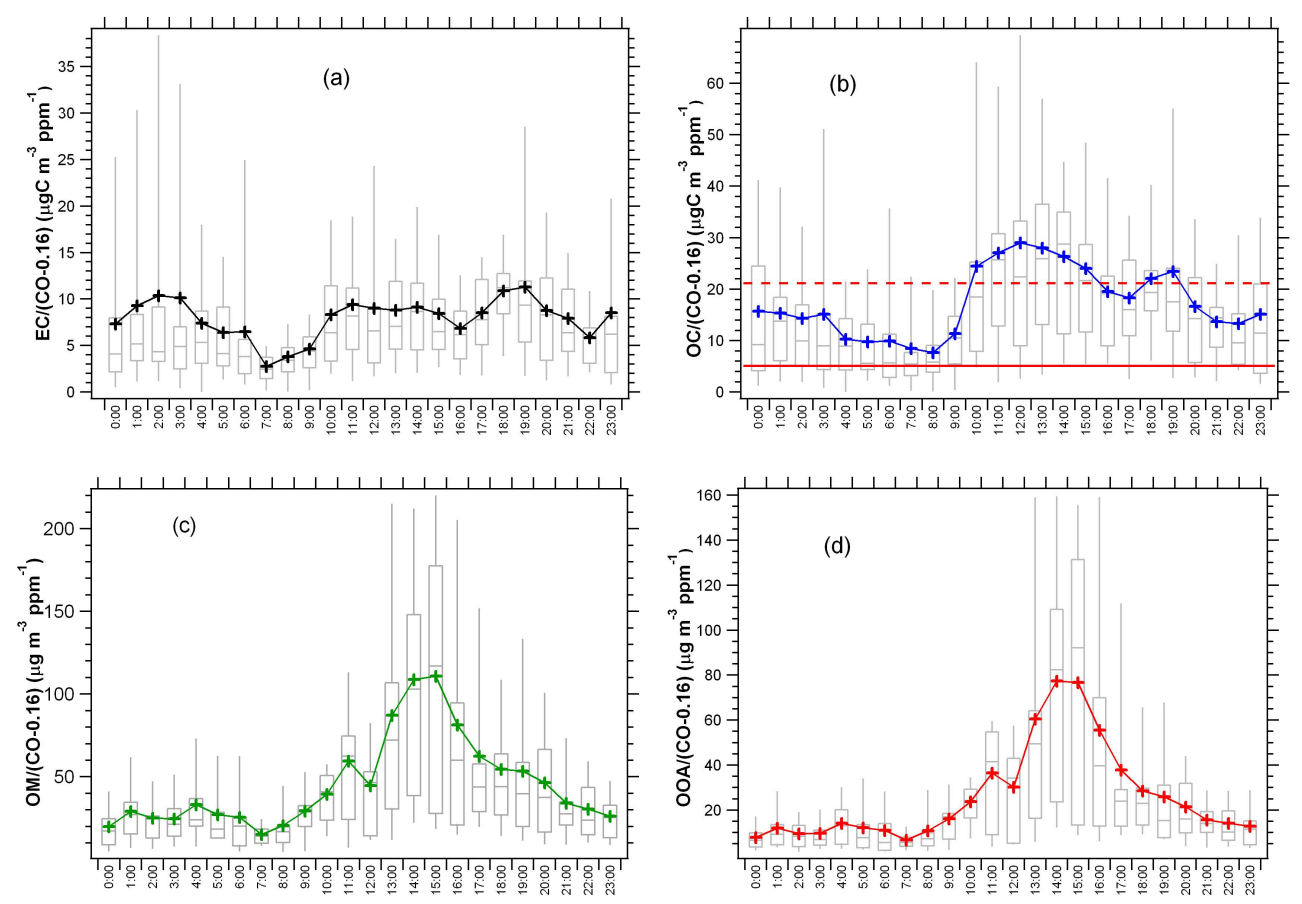

Fig. 6. Diurnal variations of different aerosol species EC (a), OC (b), OM (c), OOA (d) versus (CO-0.16). The value of $0.16 \mathrm{ppm}$ was CO background concentration. The box plot is the same meaning as Fig. 5 showed. The red lines in Fig. $6 \mathrm{~b}$ indicate estimates for the direct emissions (solid) and secondary formation after half a day of processing (dotted) of organic aerosol in the northeastern US (de Gouw et al., 2009). 
observed, especially in the afternoon when the photochemical activities were strong. Yue et al. (2010) also found the secondary transformation played an important role on regional transport in the PRD region. Thus, the quantification of secondary organic carbon in OC concentration was examined in the following part.

\subsection{Estimation of secondary organic carbon by modified EC tracer method}

EC tracer method is usually adopted to estimate the SOC concentrations. This method assumes EC is a tracer of primary emissions and primary $\mathrm{OC}$ also comes from the same combustion sources with EC. Through calculating the emission ratio of primary $\mathrm{OC}$ to $\mathrm{EC}$, we can calculate $\mathrm{POC}$ and SOC concentrations $(\mathrm{POC}+\mathrm{SOC}=\mathrm{OC})$. So it is a key step to determine $(\mathrm{OC} / \mathrm{EC})_{\text {pri }}$ for the SOC estimation by EC tracer method.

In previous studies, the $(\mathrm{OC} / \mathrm{EC})_{\text {pri }}$ has been estimated on the basis of two methods: (1) using the ratios between ambient $\mathrm{OC}$ and EC when primary source emissions dominate and the secondary organic aerosol formations are expected to be low (Turpin and Huntzicker, 1995). However it is really difficult to draw a clear demarcation between primary and secondary source dominant period. The other estimation method (2) is using those ratios derived from emission inventories of OC and EC (Gray et al., 1986). Although emission inventories of $\mathrm{OC}$ and $\mathrm{EC}$ are widely used, the uncertainties of $(\mathrm{OC} / \mathrm{EC})_{\text {pri }}$ derived from emission inventories is immense (Cabada et al., 2004; Millet et al., 2005), especially for the emissions inventories in China.

Previously, Xiao et al. (2011) used a rough EC tracer method (set $(\mathrm{OC} / \mathrm{EC})_{\text {pri }}$ to 1.1$)$ to separate POC and SOC basing on this dataset. To improve the accuracy of SOC estimation, the traditional EC tracer method is modified to obtain a more specific $(\mathrm{OC} / \mathrm{EC})_{\text {pri }}$ in this study, that is, to combine traditional EC tracer method with source tracer ratio method. The source tracer ratio method was first introduced by Millet et al. (2005), who applied this method to Pittsburgh EC/OC dataset. The good agreement of source tracer ratio method with other approaches has been confirmed in Zhang et al. (2005). Detailed description about source tracer ratio method can be obtained in Millet et al. (2005). The modified EC tracer method is explained below. An unraveled OC equation was given by:

$$
\begin{aligned}
& \mathrm{OC}_{\text {total }}=\mathrm{OC}_{\mathrm{pri}}+\mathrm{OC}_{\mathrm{sec}}+\mathrm{OC}_{\mathrm{non}}=\mathrm{EC}_{\mathrm{a}} \times(\mathrm{OC} / \mathrm{EC})_{\mathrm{pri}} \\
& \quad+\mathrm{OC}_{\mathrm{sec}}+\mathrm{OC}_{\mathrm{non}} \\
& \mathrm{OC}_{\mathrm{sec}}=\mathrm{OC}_{\text {total }}-\mathrm{EC}_{\mathrm{a}} \times(\mathrm{OC} / \mathrm{EC})_{\text {pri }}-\mathrm{OC}_{\mathrm{non}}
\end{aligned}
$$

Here, $\mathrm{OC}_{\text {total }}$ is the measured $\mathrm{OC}$ concentrations, which is separated into three parts: primary organic carbon $\left(\mathrm{OC}_{\mathrm{pri}}\right)$ and secondary formation organic carbon $\left(\mathrm{OC}_{\mathrm{sec}}\right)$, as well as a regional background $\left(\mathrm{OC}_{\mathrm{non}}\right)$. $(\mathrm{OC} / \mathrm{EC})_{\mathrm{pri}}$ is the initially emission ratio between $\mathrm{OC}_{\mathrm{pri}}$ and $\mathrm{EC}$ from combustion source. $\mathrm{EC}_{\mathrm{a}}$ represents the measured ambient concentrations of EC.

$\mathrm{OC}_{\text {non }}$ is referred to the non-combustion $\mathrm{OC}$ from biogenic primary $\mathrm{OC}$ or regional OC background. The intercept of the OC/EC regression line is regarded as the $\mathrm{OC}_{\text {non }}$. The $\mathrm{OC}_{\mathrm{non}}$ in normal days was around -0.2 , which suggested $\mathrm{OC}$ from non-combustion emissions was small and does not significantly affect our results. Thus, $\mathrm{OC}_{\mathrm{non}}$ in normal days was not considered here, which is also consistent with previous studies (Lim and Turpin, 2002; Cabada et al., 2004; Polidori et al., 2006). So the equation can be simplified to Eq. (3):

$\mathrm{OC}_{\mathrm{sec}}=\mathrm{OC}_{\text {total }}-\mathrm{EC}_{\mathrm{a}} \times(\mathrm{OC} / \mathrm{EC})_{\text {pri }}$

In the Eq. (3), only $\mathrm{OC}_{\mathrm{sec}}$ and $(\mathrm{OC} / \mathrm{EC})_{\text {pri }}$ are unknown. So to calculate $\mathrm{OC}_{\mathrm{sec}}$ concentrations, the key is to find out an exact $(\mathrm{OC} / \mathrm{EC})_{\mathrm{pri}}$. In the modified EC tracer method, the first step is to find a proper period dataset to calculate $(\mathrm{OC} / \mathrm{EC})_{\text {pri }}$. From the discussions of diurnal variation of carbonaceous aerosol in normal days, the sources of carbonaceous aerosol are different between day and night. So, the $(\mathrm{OC} / \mathrm{EC})_{\text {pri }}$ calculation will be separated into two datasets: OC and EC in the day (06:00-18:00) and in the night (18:0006:00). From the Eq. (3), when $(\mathrm{OC} / \mathrm{EC})$ pri is given in a fixed reasonable range, $\mathrm{OC}_{\mathrm{sec}}$ and the coefficient of determination $\left(R^{2}\right)$ between $\mathrm{OC}_{\mathrm{sec}}$ and $\mathrm{EC}$ within each dataset could be correspondingly determined. By varying (OC/EC) pri value in a rational range (0-15 is used here by a step of 0.001$)$, a series of correlation coefficient $R^{2}$ between $\mathrm{OC}_{\mathrm{sec}}$ and $\mathrm{EC}$ can be obtained. A plot of the $R^{2}$ between $\mathrm{OC}_{\mathrm{sec}}$ and $\mathrm{EC}$ with the $(\mathrm{OC} / \mathrm{EC})_{\text {pri }}$ values can be drawn (e.g. Fig. $7 \mathrm{~b}$ and c). If we assume that $\mathrm{OC}_{\mathrm{sec}}$ and $\mathrm{EC}$ were from different sources, the proper $(\mathrm{OC} / \mathrm{EC})_{\text {pri }}$ should be the one that corresponds to the minimum $R^{2}$ value or when $\mathrm{OC}_{\mathrm{sec}}$ correlated with $\mathrm{EC}$ worst. It is worthy to note that the assumption of low correlation between $\mathrm{OC}_{\mathrm{sec}}$ and $\mathrm{EC}$ may be violated by the fact that the SOC can be formed from primary organic particulate emissions (Robinson et al., 2007; Grieshop et al., 2009).

In order to check the reliability of the modified EC tracer method, $(\mathrm{OC} / \mathrm{EC})_{\text {pri }}$ in local emissions influence days was also calculated as an example in Fig. 7a. From 23 to 25 July, there were very strong primary emissions at night, which was discussed in Sect. 3.1. High linear correlation between OC and EC also indicated that the $\mathrm{OC}$ was mainly dominated by primary sources. The regression slope between OC and EC showed the $(\mathrm{OC} / \mathrm{EC})_{\text {pri }}$ was 1.1 (Fig. 7a). Meanwhile, the (OC/EC) pri by modified EC tracer method was 1.04 (Fig. 7b). The agreement between these two results from linear regression and modified EC tracer method indicates the reasonableness of the latter method.

The $(\mathrm{OC} / \mathrm{EC})_{\text {pri }}$ for the day and night in normal days were determined to be 1.57 and 1.42 , respectively (Fig. 7c). The values are higher than the ratio calculated for primary emission days (1.04). this suggests the different emission sources of $\mathrm{OC}$ and EC between primary emission days and normal days. However, the ratios in emission inventory both 

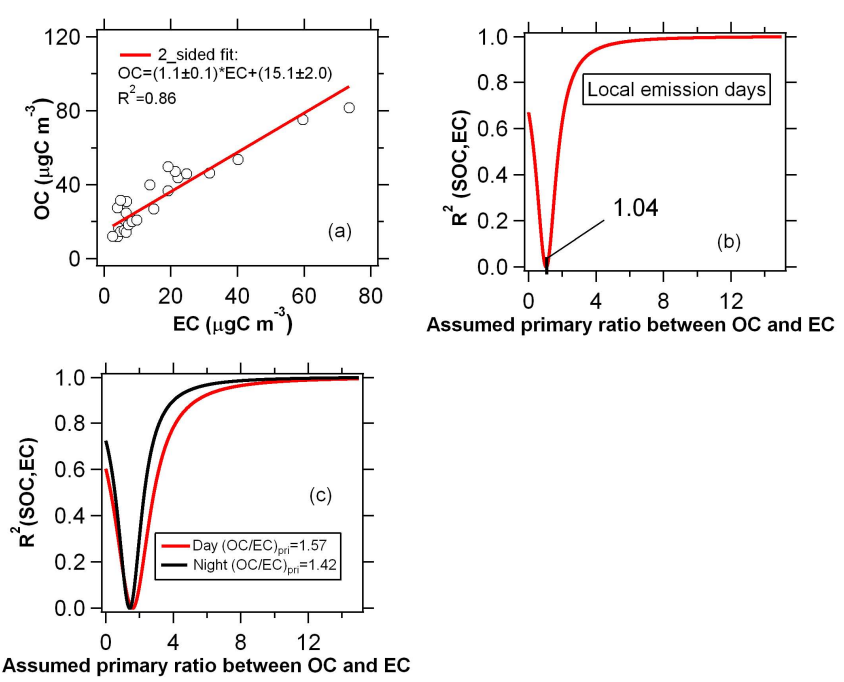

Fig. 7. (a) Scatter plot between OC and EC during the nights of local primary emission days. (b) $R^{2}$ between SOC and EC is as a function of the primary emission ratio between OC and EC in the local emission influence days and (c) normal days of the whole campaign.

for China (1.78) and Guangdong Province (2.18) (Zhang et al., 2009) are higher than the determined (OC/EC) pri values in this study. The SOC concentration calculated by two (OC/EC $)_{\text {pri }}$ methods mentioned above and the comparisons to modified EC tracer method can be obtained in the supplementary material. The detailed information on inventory OC and EC can be obtained in Bond et al. (2004).

Overall, the SOC concentrations in normal days could be up to $15.6 \mu \mathrm{g} \mathrm{m}^{-3}$, with an average concentration of $2.0 \pm 2.3 \mu \mathrm{g} \mathrm{m}^{-3}$. The SOC fractions in OC ranged up to $80 \%$, with an average of $47 \%$ (Fig. 8a). The SOC/OC or WSOC/OC in other sites of the world are also given in the Table 2. SOC/OC ratio at BG site was higher the value in Guangzhou city and comparable to those of other suburban sites, as shown in Table 2. The concentrations of WSOC correlated well with those of SOC with the $R^{2} 0.7$ and regression slope $0.7 \pm 0.03$, indicating most of the WSOC were SOC (Fig. 8b). The correlation between SOC and OOA was good $\left(R^{2}=0.6\right)$ (Fig. 8c). The regression slope between them was 0.31 , a little lower than the result in Pittsburgh $(\sim 0.45)$ (Zhang et al., 2005), indicating that there were more noncarbon elements (e.g. O, N) in the OOA of BG site. However, HOA correlated POC very well (Fig. 8d) and $R^{2}$ was about 0.76. The regression slope between POC and HOA was about 0.9 , indicating that most or all HOA was POC. The POC and HOA ratio is similar to result $\sim 0.8$ at T0 site in Mexico City (Aiken et al., 2009) and $\sim 0.8$ in Pittsburgh as well (Zhang et al., 2005).

It should be noted that strong secondary formation episode occurred from 19 to 21 July during the whole campaign with
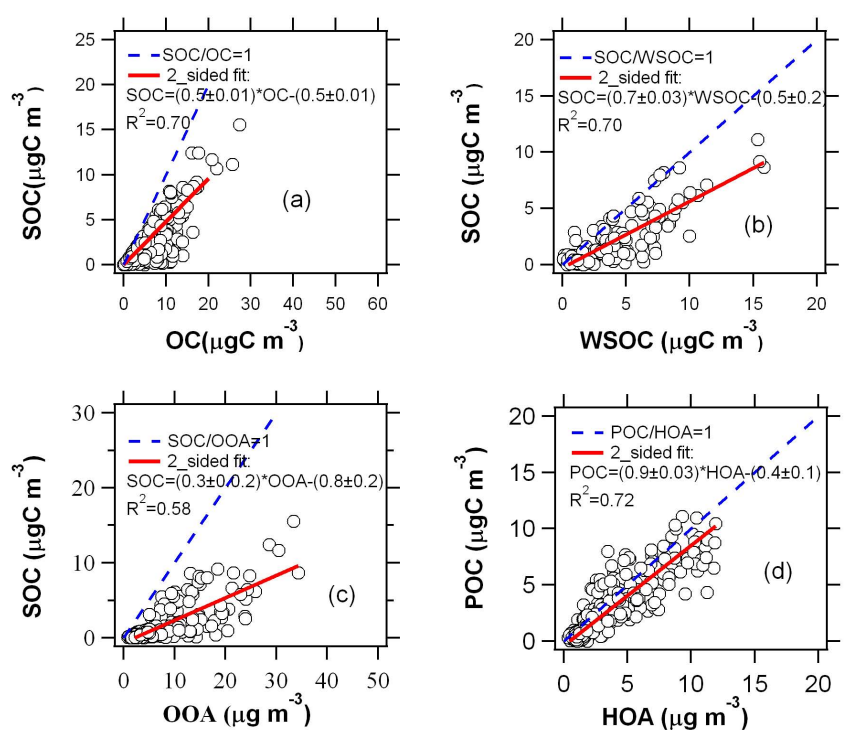

Fig. 8. Scatter plots of different organic aerosols at BG site, OC (a), WSOC (b), OOA (c) versus SOC and POC versus HOA (d).

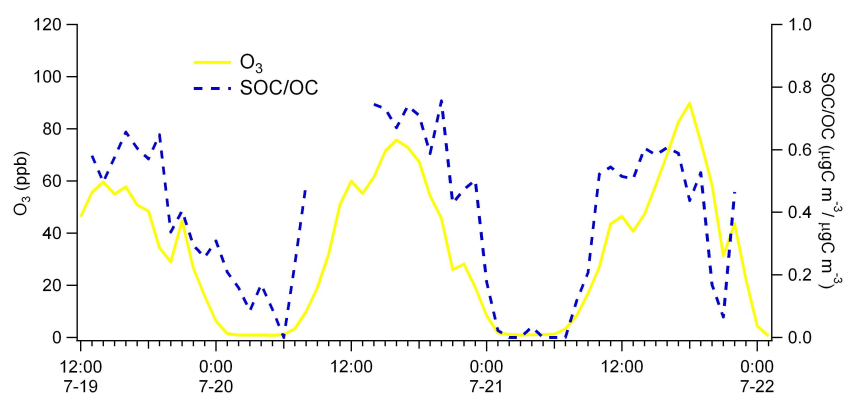

Fig. 9. The variation of $\mathrm{SOC} / \mathrm{OC}$ ratio and $\mathrm{O}_{3}$ during the photochemical active periods of 19 to 21, July 2006.

the enhancement of strong solar radiation and weak winds (Fig. 3). Therefore, this episode was used to evaluate the estimation of the secondary formation at BG site (Fig. 9). The ratio of SOC to OC showed a distinct diurnal profile with highest ratio in the afternoon and lowest at night, matching well with the variations of $\mathrm{O}_{3}$ concentrations. The average SOC in the afternoon from 14:00 to 17:00 accounted for $64 \%$ of OC within these three days.

\section{Conclusions}

Carbonaceous aerosol was measured at Back Garden (BG), a rural site of the PRD region during PRIDE-PRD 2006 campaign in July 2006. The concentrations of carbonaceous aerosol varied dramatically due to the effects from both extreme meteorology conditions (e.g. typhoon and precipitation) and anthropogenic emission sources (e.g. biomass burning) in the summer of PRD. 
The similar diurnal profiles for OC and EC were observed, with two peaks at night and in early morning, and were attributed to the local emissions accumulation in shallow boundary layer and rush hour emissions in the early morning. Minimum values were measured in the afternoon due to the dilution effect by the lifted boundary layer. The enhancement ratio of OC showed similar diurnal variations to oxygenated organic aerosol (OOA) with a relative high peak in the afternoon, indicating the strong photochemical secondary formation.

The modified EC tracer method was adopted to estimate secondary organic carbon (SOC) concentrations. According to the distinct diurnal characteristic of carbonaceous aerosols, $(\mathrm{OC} / \mathrm{EC})_{\text {pri }}$ was calculated for the data points in day and night, respectively. The average SOC concentration (normal days) at BG site was $2.0 \pm 2.3 \mu \mathrm{gC} \mathrm{m}{ }^{-3}$, accounting for $47 \%$ of the OC mass concentrations, and could be up to $80 \%$. Good correlations were observed for estimated SOC with OOA and WSOC, and estimated POC with HOA, which proved the results by the modified EC tracer method are reliable in this paper.

\section{Supplementary material related to this article is available online at: http://www.atmos-chem-phys.net/12/1811/2012/ acp-12-1811-2012-supplement.pdf.}

Acknowledgements. This work is supported by the National Natural Science Foundation of China (20977001, 21025728), and also supported by the China Ministry of Environmental Protection's Special Funds for Scientific Research on Public Welfare (201009002) and EU FP-7 CityZen project (212095). We would like sincerely thank the PRIDE-PRD 2006 team and the modifications and suggestions made by Liu Ying and Yuan Bin.

Edited by: S. C Liu

\section{References}

Aiken, A. C., Decarlo, P. F., Kroll, J. H., Worsnop, D. R., Huffman, J. A., Docherty, K. S., Ulbrich, I. M., Mohr, C., Kimmel, J. R., Sueper, D., Sun, Y., Zhang, Q., Trimborn, A., Northway, M., Ziemann, P. J., Canagaratna, M. R., Onasch, T. B., Alfarra, M. R., Prevot, A. S. H., Dommen, J., Duplissy, J., Metzger, A., Baltensperger, U., and Jimenez, J. L.: O/C and OM/OC ratios of primary, secondary, and ambient organic aerosols with high-resolution time-of-flight aerosol mass spectrometry, Environ. Sci. Technol., 42, 4478-4485, doi:10.1021/Es703009q, 2008.

Aiken, A. C., Salcedo, D., Cubison, M. J., Huffman, J. A., DeCarlo, P. F., Ulbrich, I. M., Docherty, K. S., Sueper, D., Kimmel, J. R., Worsnop, D. R., Trimborn, A., Northway, M., Stone, E. A., Schauer, J. J., Volkamer, R. M., Fortner, E., de Foy, B., Wang, J., Laskin, A., Shutthanandan, V., Zheng, J., Zhang, R., Gaffney, J., Marley, N. A., Paredes-Miranda, G., Arnott, W. P., Molina, L. T., Sosa, G., and Jimenez, J. L.: Mexico City aerosol analysis during
MILAGRO using high resolution aerosol mass spectrometry at the urban supersite (T0) - Part 1: Fine particle composition and organic source apportionment, Atmos. Chem. Phys., 9, 66336653, doi:10.5194/acp-9-6633-2009, 2009.

Akagi, S. K., Yokelson, R. J., Wiedinmyer, C., Alvarado, M. J., Reid, J. S., Karl, T., Crounse, J. D., and Wennberg, P. O.: Emission factors for open and domestic biomass burning for use in atmospheric models, Atmos. Chem. Phys., 11, 4039-4072, doi:10.5194/acp-11-4039-2011, 2011.

Andreae, M. O. and Gelencsér, A.: Black carbon or brown carbon? The nature of light-absorbing carbonaceous aerosols, Atmos. Chem. Phys., 6, 3131-3148, doi:10.5194/acp-6-3131-2006, 2006.

Andreae, M. O. and Merlet, P.: Emission of trace gases and aerosols from biomass burning, Global Biogeochem. Cy., 15, 955-966, 2001.

Bond, T. C., Streets, D. G., Yarber, K. F., Nelson, S. M., Woo, J.H., and Klimont, Z.: A technology-based global inventory of black and organic carbon emissions from combustion, J. Geophys. Res., 109, D14203, doi:10.1029/2003jd003697, 2004.

Cabada, J. C., Pandis, S. N., Subramanian, R., Robinson, A. L., Polidori, A., and Turpin, B.: Estimating the secondary organic aerosol contribution to $\mathrm{PM}_{2.5}$ using the EC tracer method, Aerosol Sci. Tech., 38, 140-155, doi:10.1080/02786820390229084, 2004.

Cao, J. J., Lee, S. C., Ho, K. F., Zhang, X. Y., Zou, S. C., Fung, K., Chow, J. C., and Watson, J. G.: Characteristics of carbonaceous aerosol in Pearl River Delta Region, China during 2001 winter period, Atmos. Environ., 37, 1451-1460, doi:10.1016/S13522310(02)01002-6, 2003.

de Gouw, J. A., Welsh-Bon, D., Warneke, C., Kuster, W. C., Alexander, L., Baker, A. K., Beyersdorf, A. J., Blake, D. R., Canagaratna, M., Celada, A. T., Huey, L. G., Junkermann, W., Onasch, T. B., Salcido, A., Sjostedt, S. J., Sullivan, A. P., Tanner, D. J., Vargas, O., Weber, R. J., Worsnop, D. R., Yu, X. Y., and Zaveri, R.: Emission and chemistry of organic carbon in the gas and aerosol phase at a sub-urban site near Mexico City in March 2006 during the MILAGRO study, Atmos. Chem. Phys., 9, 3425-3442, doi:10.5194/acp-9-3425-2009, 2009.

Garland, R. M., Yang, H., Schmid, O., Rose, D., Nowak, A., Achtert, P., Wiedensohler, A., Takegawa, N., Kita, K., Miyazaki, Y., Kondo, Y., Hu, M., Shao, M., Zeng, L. M., Zhang, Y. H., Andreae, M. O., and Pschl, U.: Aerosol optical properties in a rural environment near the mega-city Guangzhou, China: implications for regional air pollution, radiative forcing and remote sensing, Atmos. Chem. Phys., 8, 5161-5186, doi:10.5194/acp-85161-2008, 2008.

Gnauk, T., Müller, K., van Pinxteren, D., He, L.-Y., Niu, Y., Hu, M., and Herrmann, H.: Size-segregated particulate chemical composition in Xinken, Pearl River Delta, China: OC/EC and organic compounds, Atmos. Environ., 42, 6296-6309, doi:10.1016/j.atmosenv.2008.05.001, 2008.

Gray, H. A., Cass, G. R., Huntzicker, J. J., Heyerdahl, E. K., and Rau, J. A.: Characteristics of Atmospheric Organic and Elemental Carbon Particle Concentrations in Los-Angeles, Environ. Sci. Technol., 20, 580-589, 1986.

Grieshop, A. P., Logue, J. M., Donahue, N. M., and Robinson, A. L.: Laboratory investigation of photochemical oxidation of organic aerosol from wood fires 1: measurement and simulation of 
organic aerosol evolution, Atmos. Chem. Phys., 9, 1263-1277, doi:10.5194/acp-9-1263-2009, 2009.

Hagler, G. S. W., Bergin, M. H., Salmon, L. G., Yu, J. Z., Wan, E. C. H., Zheng, M., Zeng, L. M., Kiang, C. S., Zhang, Y. H., Lau, A. K. H., and Schauer, J. J.: Source areas and chemical composition of fine particulate matter in the Pearl River Delta region of China, Atmos. Environ., 40, 3802-3815, doi:10.1016/j.atmosenv.2006.02.032, 2006.

Han, Y. M., Han, Z. W., Cao, J. J., Chow, J. C., Watson, J. G., An, Z. S., Liu, S. X., and Zhang, R. J.: Distribution and origin of carbonaceous aerosol over a rural high-mountain lake area, Northern China and its transport significance, Atmos. Environ., 42, 2405-2414, doi:10.1016/j.atmosenv.2007.12.020, 2008.

He, L. Y., Hu, M., Zhang, Y. H., Huang, X. F., and Yao, T. T.: Fine particle emissions from on-road vehicles in the Zhujiang Tunnel, China, Environ. Sci. Technol., 42, 4461-4466, doi:10.1021/Es7022658, 2008.

Ho, K. F., Lee, S. C., Cao, J. J., Li, Y. S., Chow, J. C., Watson, J. G., and Fung, K.: Variability of organic and elemental carbon, water soluble organic carbon, and isotopes in Hong Kong, Atmos. Chem. Phys., 6, 4569-4576, doi:10.5194/acp-6-4569-2006, 2006.

Kondo, Y., Miyazaki, Y., Takegawa, N., Miyakawa, T., Weber, R. J., Jimenez, J. L., Zhang, Q., and Worsnop, D. R.: Oxygenated and water-soluble organic aerosols in Tokyo, J. Geophys. Res.Atmos., 112, D01203, doi:10.1029/2006JD007056, 2007.

Li, X., Brauers, T., Shao, M., Garland, R. M., Wagner, T., Deutschmann, T., and Wahner, A.: MAX-DOAS measurements in southern China: retrieval of aerosol extinctions and validation using ground-based in-situ data, Atmos. Chem. Phys., 10, 2079 2089, doi:10.5194/acp-10-2079-2010, 2010.

Lim, H. J. and Turpin, B. J.: Origins of primary and secondary organic aerosol in Atlanta: Results' of time-resolved measurements during the Atlanta supersite experiment, Environ. Sci. Technol., 36, 4489-4496, doi:10.1021/Es0206487, 2002.

Lin, P., Hu, M., Deng, Z., Slanina, J., Han, S., Kondo, Y., Takegawa, N., Miyazaki, Y., Zhao, Y., and Sugimoto, N.: Seasonal and diurnal variations of organic carbon in $\mathrm{PM}_{2.5}$ in Beijing and the estimation of secondary organic carbon, J. Geophys. Res.-Atmos., 114, D00G11, doi:10.1029/2008JD010902, 2009.

Millet, D. B., Donahue, N. M., Pandis, S. N., Polidori, A., Stanier, C. O., Turpin, B. J., and Goldstein, A. H.: Atmospheric volatile organic compound measurements during the Pittsburgh Air Quality Study: Results, interpretation, and quantification of primary and secondary contributions, J. Geophys. Res.-Atmos., 110, D07S07, doi:10.1029/2004jd004601, 2005.

Miyazaki, Y., Kondo, Y., Shiraiwa, M., Takegawa, N., Miyakawa, T., Han, S., Kita, K., Hu, M., Deng, Z. Q., Zhao, Y., Sugimoto, N., Blake, D. R., and Weber, R. J.: Chemical characterization of water-soluble organic carbon aerosols at a rural site in the Pearl River Delta, China, in the summer of 2006, J. Geophys. Res.Atmos., 114, D14208, doi:10.1029/2009jd011736, 2009.

Odum, J. R., Jungkamp, T. P. W., Griffin, R. J., Flagan, R. C., and Seinfeld, J. H.: The atmospheric aerosol-forming potential of whole gasoline vapor, Science, 276, 96-99, 1997.

Park, S. S., Harrison, D., Pancras, J. P., and Ondov, J. M.: Highly time-resolved organic and elemental carbon measurements at the Baltimore Supersite in 2002, J. Geophys. Res.-Atmos., 110, D07S06, doi:10.1029/2004jd004610, 2005.
Polidori, A., Turpin, B. J., Lim, H. J., Cabada, J. C., Subramanian, R., Pandis, S. N., and Robinson, A. L.: Local and regional secondary organic aerosol: Insights from a year of semi-continuous carbon measurements at Pittsburgh, Aerosol Sci. Tech., 40, 861872, doi:10.1080/02786820600754649, 2006.

Robinson, A. L., Donahue, N. M., Shrivastava, M. K., Weitkamp, E. A., Sage, A. M., Grieshop, A. P., Lane, T. E., Pierce, J. R., and Pandis, S. N.: Rethinking organic aerosols: Semivolatile emissions and photochemical aging, Science, 315, 1259-1262, doi:10.1126/science.1133061, 2007.

Schauer, J. J., Rogge, W. F., Hildemann, L. M., Mazurek, M. A., and Cass, G. R.: Source apportionment of airborne particulate matter using organic compounds as tracers, Atmos. Environ., 30, 3837-3855, 1996.

Seinfeld, J. H. and Pandis, S. N.: Atmospheric Chemistry and Physics: from Air Pollution to Climate Change, John Wiley, New York, 1998.

Takegawa, N., Miyakawa, T., Watanabe, M., Kondo, Y., Miyazaki, Y., Han, S., Zhao, Y., van Pinxteren, D., Bruggemann, E., Gnauk, T., Herrmann, H., Xiao, R., Deng, Z., Hu, M., Zhu, T., and Zhang, Y.: Performance of an Aerodyne Aerosol Mass Spectrometer (AMS) during Intensive Campaigns in China in the Summer of 2006, Aerosol Sci. Tech., 43, 189-204, doi:10.1080/02786820802582251, 2009.

Tao, J., Ho, K. F., Chen, L. G., Zhu, L. H., Han, J. L., and Xu, Z. C.: Effect of chemical composition of $\mathrm{PM}_{2.5}$ on visibility in Guangzhou, China, 2007 spring, Particuology, 7, 68-75, doi:10.1016/j.partic.2008.11.002, 2009.

Turpin, B. J. and Huntzicker, J. J.: Identification of Secondary Organic Aerosol Episodes and Quantitation of Primary and Secondary Organic Aerosol Concentrations during Scaqs, Atmos. Environ., 29, 3527-3544, 1995.

Verma, R. L., Sahu, L. K., Kondo, Y., Takegawa, N., Han, S., Jung, J. S., Kim, Y. J., Fan, S., Sugimoto, N., Shammaa, M. H., Zhang, Y. H., and Zhao, Y.: Temporal variations of black carbon in Guangzhou, China, in summer 2006, Atmos. Chem. Phys., 10, 6471-6485, doi:10.5194/acp-10-6471-2010, 2010.

Viana, M., Maenhaut, W., ten Brink, H. M., Chi, X., Weijers, E., Querol, X., Alastuey, A., Mikuska, P., and Vecera, Z.: Comparative analysis of organic and elemental carbon concentrations in carbonaceous aerosols in three European cities, Atmos. Environ., 41, 5972-5983, doi:10.1016/j.atmosenv.2007.03.035, 2007.

Watson, J. G., Chow, J. C., and Houck, J. E.: $\mathrm{PM}_{2.5}$ chemical source profiles for vehicle exhaust, vegetative burning, geological material, and coal burning in Northwestern Colorado during 1995, Chemosphere, 43, 1141-1151, doi:10.1016/s00456535(00)00171-5, 2001.

Xiao, R., Takegawa, N., Zheng, M., Kondo, Y., Miyazaki, Y., Miyakawa, T., Hu, M., Shao, M., Zeng, L., Gong, Y., Lu, K., Deng, Z., Zhao, Y., and Zhang, Y. H.: Characterization and source apportionment of submicron aerosol with aerosol mass spectrometer during the PRIDE-PRD 2006 campaign, Atmos. Chem. Phys., 11, 6911-6929, doi:10.5194/acp-11-6911-2011, 2011.

Yu, H., Wu, C., Wu, D., and Yu, J. Z.: Size distributions of elemental carbon and its contribution to light extinction in urban and rural locations in the pearl river delta region, China, Atmos. Chem. Phys., 10, 5107-5119, doi:10.5194/acp-10-5107-2010, 2010.

Yu, X.-Y., Cary, R. A., and Laulainen, N. S.: Primary and secondary 
organic carbon downwind of Mexico City, Atmos. Chem. Phys., 9, 6793-6814, doi:10.5194/acp-9-6793-2009, 2009.

Yue, D. L., Hu, M., Wu, Z. J., Guo, S., Wen, M. T., Nowak, A., Wehner, B., Wiedensohler, A., Takegawa, N., Kondo, Y., Wang, X. S., Li, Y. P., Zeng, L. M., and Zhang, Y. H.: Variation of particle number size distributions and chemical compositions at the urban and downwind regional sites in the Pearl River Delta during summertime pollution episodes, Atmos. Chem. Phys., 10, 9431-9439, doi:10.5194/acp-10-9431-2010, 2010.
Zhang, Q., Worsnop, D. R., Canagaratna, M. R., and Jimenez, J. L.: Hydrocarbon-like and oxygenated organic aerosols in Pittsburgh: insights into sources and processes of organic aerosols, Atmos. Chem. Phys., 5, 3289-3311, doi:10.5194/acp-5-32892005, 2005.

Zhang, Q., Streets, D. G., Carmichael, G. R., He, K. B., Huo, H., Kannari, A., Klimont, Z., Park, I. S., Reddy, S., Fu, J. S., Chen, D., Duan, L., Lei, Y., Wang, L. T., and Yao, Z. L.: Asian emissions in 2006 for the NASA INTEX-B mission, Atmos. Chem. Phys., 9, 5131-5153, doi:10.5194/acp-9-5131-2009, 2009. 